\title{
THE BIOSYNTHESIS OF PHARMACOLOGICALLY ACTIVE COMPOUNDS IN CALOPHYLLUM BRASILIENSE SEEDLINGS IS INFLUENCED BY CALCIUM AND POTASSIUM UNDER HYDROPONIC CONDITIONS
}

\author{
LA BIOSÍNTESIS DE COMPUESTOS FARMACOLÓGICAMENTE ACTIVOS EN PLÁNTULAS DE \\ CALOPHYLLUM BRASILIENSE ESTÁ INFLUENCIADA POR EL CALCIO Y EL POTASIO EN \\ CONDICIONES HIDROPÓNICAS
}

\author{
Jorge Ivan Castillo-Arellano ${ }^{1,4}$, Helia Reyna Osuna-Fernández¹, Marius Mumbru-Massip², Rocío Gómez- \\ CANCINO ${ }^{3}$, AND RICARDO REYES-CHILPA**
}

\begin{abstract}
${ }^{1}$ Faculty of Sciences, National University Autonomous of Mexico, Mexico City.
${ }^{2}$ Faculty of Pharmacy, University of Barcelona; Barcelona, Spain

${ }^{3}$ Technology University of Mixteca, Oaxaca, Mexico

${ }^{4}$ Institute of Chemistry, National University Autonomous of Mexico, Mexico City.
\end{abstract}

*Corresponding author: chilpa@unam.mx

\begin{abstract}
Background: The influence of soil nutrients on biosynthesis of secondary metabolites from tropical trees has been poorly investigated. Questions: Does the deprival of $\mathrm{Ca}^{2+}$ and $\mathrm{K}^{+}$influence the production of pharmacologically active compounds in the seedling of Calophyllum brasiliense?

Species study: Calophyllum brasiliense Cambess.

Study site: Los Tuxtlas, Veracruz, Mexico; November 2005 to November 2009.

Methods: The seedlings were obtained from seeds and subjected to different hydroponic treatments: 1) modified Hoagland solution (MHS), 2) MHS- $\mathrm{Ca}^{2+}$, and 3) MHS-K . Growth, height, foliar biomass, and HPLC analysis were performed after 7 months.

Results: Under hydroponic conditions $\mathrm{Ca}^{2+}$ and $\mathrm{K}^{+}$deficiency induced the mortality of $53 \%$ and $28 \%$ of the seedlings, respectively. The foliar biomass, and plant height of the survivors were also drastically reduced. MHS- $\mathrm{K}^{+}$treatment induced a 15 , 4.2 and 4.3 -fold decrease for calanolides B, C, and apetalic acid in the leaves, respectively. MHS- $\mathrm{Ca}^{2+}$ treatment induced a decrease of 4.3, and 2.4-fold for calanolide B, and $\mathrm{C}$, respectively.

Conclusion: $\mathrm{Ca}^{2+}$ is essential for survival of $C$. brasiliense seedlings under hydroponic conditions, $\mathrm{Ca}^{2+}$ and $\mathrm{K}^{+}$are critical for growth, foliar production, and biosynthesis of apetalic acid, and calanolide B.
\end{abstract}

Keywords: Apetalic acid, calanolides, Calophyllum brasiliense, hydroponic, soil nutrients.

\section{Resumen}

Antecedentes: La influencia de los nutrientes del suelo en la biosíntesis de los metabolitos secundarios en árboles tropicales ha sido poco estudiada.

Preguntas: ¿La carencia de $\mathrm{Ca}^{2+} \mathrm{y} \mathrm{K}^{+}$afecta la producción de compuestos farmacológicamente activos en plántulas de Calophyllum brasiliense?

Especie de estudio: Calophyllum brasiliense Cambess.

Sitio de estudio: Los Tuxtlas, Veracruz, México; noviembre de 2005 a noviembre de 2009.

Métodos: Las plántulas se obtuvieron a partir de semillas y se sometieron a diferentes tratamientos hidropónicos: 1) solución modificada de Hoagland (MHS), 2) MHS-Ca ${ }^{2+}$, y 3 ) MHS-K . Se evaluó el crecimiento, peso, biomasa y análisis mediante HPLC después de 7 meses.

Resultados: La deficiencia de $\mathrm{Ca}^{2+} \mathrm{y} \mathrm{K}^{+}$en condiciones hidropónicas indujo la mortalidad del $53 \%$ y $28 \%$ de las plántulas respectivamente. La biomasa foliar y la altura de las plántulas sobrevivientes se redujo. El tratamiento de MHS-K ${ }^{+}$provocó una disminución de los calanólidos $\mathrm{B}, \mathrm{C}$, y del ácido apetálico de 15, 4.2 y 4.3 veces en las hojas respectivamente. El tratamiento de MHS-Ca ${ }^{2+}$ provocó una disminución de 4.3 y 2.4 veces para los calanólidos $\mathrm{B}$ y $\mathrm{C}$ respectivamente.

Conclusión: $\mathrm{El} \mathrm{Ca}^{2+}$ es esencial para la supervivencia de las plántulas de C. brasiliense, el $\mathrm{Ca}^{2+}$ and $\mathrm{K}^{+}$son importantes para el crecimiento, producción foliar y biosíntesis del ácido apetálico y el calanólido B.

Palabras clave: Ácido apetálico, calanólidos, Calophyllum brasiliense, hidroponia, nutrientes del suelo.

This is an open access article distributed under the terms of the Creative Commons Attribution License CCBY-NC (4.0) international https://creativecommons.org/licences/by-nc/4.0/ 
Biosynthesis of secondary plant metabolites is under genetic control, but may differ among species due to environmental conditions, such as temperature, precipitation, UV radiation, wet and dry season (Akula \& Ravishankar 2011, Pavarini et al. 2012, Lim et al. 2017), fungal infections (Churngchow \& Rattarasarn 2001), and owing to the content of soil macro and micronutrients (Verma \& Shukla 2015, Sampaio et al. 2016, Borges et al. 2017).

Until now, the influence of mineral nutrition on biosynthesis of secondary metabolites has been mostly studied in herbaceous species (Verma \& Shukla 2015), but some examples are available for trees or shrubs, especially-boreal species. In the case of Salix sericea Marshall, it was observed that the fertilization with different concentrations of nitrogen-phosphorus-potassium (N-P-K) during a period of 85 days, showed that the biomass increased in parallel with the nutritional content, but the production of condensed tannins and phenylpropanoids (salicortin and 2'-cinnamoylsalicortin) decreased (Glynn et al. 2007). It has been reported that Prunus armeniaca L. fertilized with calcium ammonium nitrate (CAN) during four years favored the growth of the trees, and production of total phenolic content in comparison with the treatment with N-P-K, where the total flavonoid content was higher (Milošević et al. 2013). The cultivated Thymus leptobotrys Murb. and T. maroccanus Ball, medicinal shrubs from Morocco, had a higher production of terpenes in their essential oils when treated with N-P-K, as compared with those not fertilized. Interestingly, none of the cultivated shrubs presented higher yields compared to the wild shrubs (Alaoui et al. 2014).

The potassium soil deficiency significantly diminished the content of phenolics and tannins in the roots of Pseudotsuga menziesii (Mirb.) Franco var. glauca (Mayr) Franco seedlings, (Shaw et al. 1998); but in the case of Picea abies (L.) H.Karst. it increased the content of putrescine of the leaves (Lauchert \& Wild 1995). Increasing $\mathrm{N}$ fertilization suppressed monoterpene production in Abies grandis (Douglas ex D. Don) Lindl. (Muzika et al. 1989). Condensed tannin production decreased under fertilization in Quercus rubra L., Quercus prinus L. (Forkner \& Hunter 2000) and Quercus laevis Walter. (Cornelissen \& Stiling 2006). The content of nutrients and soil moisture associated to seasonality, up or down regulated the concentration of terpenes, resin acids, and total phenolics in Pinus sylvestris L. seedlings (Nerg et al. 1994).

In the case of tropical angiosperm trees, the influence of mineral nutrition has focused on growth and timber production (Resende et al. 2000, Boeger \& Wisniewski 2003, Martinez-Sanchez 2006, Hua et al. 2008). To our best knowledge, the only available study regarding to secondary metabolites is for Theobroma cacao L. Soil fertilization may lead trees to produce cocoa seed with smaller amounts of total polyphenols, flavan-3-ols and anthocyanins, but with larger quantities of caffeic acid aspartate, as compared with seeds from trees of unfertilized locations (Elwers et al. 2009).

Calophyllum brasiliense Cambess. (Clusiaceae) is a perennial tree of 20 to $50 \mathrm{~m}$ in height. It grows in swamp and lowlands of Evergreen Tropical and Deciduous Tropical Forests from Brazil to Mexico (Vozzo 2002, De Carvalho et al. 2006). The cultivation of $C$. brasiliense is very difficult due to recalcitrant nature of the seeds, irregular fructification and absence of natural vegetative propagation of this species (Silveira et al. 2016).

In Mexico, it has been described two chemotypes of $C$. brasiliense (Zavaleta-Mancera et al. 2011). The term chemotype has been defined as a "chemical phenotype" or the "chemical expression of a genotype" (McKee et al. 1998, Desjardins 2008). Specimens from the Mexico National Herbarium indicates CTP1 is scarce, while CTP2 is fairly more abundant (García-Zebadúa et al. 2014). The first chemotype (CTP1) of $C$. brasilense synthesizes in the leaves mammea type coumarins as majoritarian compounds (Reyes-Chilpa et al. 2004). Mammea coumarins are cytotoxic in vitro against human tumor cell lines, and Trypanosoma cruzi causing Chagas' Disease (Reyes-Chilpa et al. 2008).

The second chemotype (CTP2) of C. brasilense synthesizes in the leaves chromanones as majoritary compounds, mainly apetalic acid, and as minoritary constituents dipyrano-tetracyclic coumarins, such as calanolides $\mathrm{A}, \mathrm{B}, \mathrm{C}$, and soulatrolide (Figure 1) (Huerta-Reyes et al. 2004). Apetalic acid has showed good activity against Mycobacterium tuberculosis (Ajithabai et al. 2012), and against human KB and HeLa human tumor cell lines (Shen et al. 2004). The dipyrano-tetracyclic coumarins exhibit antiviral properties against HIV-1 and are the most important anti-HIV natural products from the pharmacological perspective (Kashman et al. 1992, Butler 2008).

The two chemotypes of $C$. brasiliense grow in the Tuxtlas region, State of Veracruz, Mexico (Huerta-Reyes et al. 2004, Reyes-Chilpa et al. 2004, Zavaleta-Mancera 2011). A preliminary sampling of altitudinal distribution of both chemotypes in the Tropical Rain Forest "Los Tuxtlas" has shown CTP1 is specially located from 200-400 m, while CTP2 from 0-200 m (García-Zebadúa et al. 2014).

In the present paper we investigated if $\mathrm{Ca}^{2+}$ or $\mathrm{K}^{+}$deprival may affect the production of the secondary metabolites apetalic acid, and calanolide $\mathrm{B}$ and $\mathrm{C}$ in the leaves of $\mathrm{Ca}$ lophyllum brasiliense chemotype 2 seedlings, subjected to hydroponic condition.

\section{Materials and methods}

Collecting seed and soil. Parent trees of C. brasiliense chemotype 2 growing wild in the State of Veracruz, Mexico were sampled to collect the unripe fruits. Trees were chosen from two contrasting areas in an altitude transect of $20 \mathrm{~km}$. "Highland" (Ejido Benigno Mendoza, $322 \mathrm{~m}$ ), and "lowland" (Tecuanapa, $25 \mathrm{~m}$ ). Soils of primary or secondary vegetation are clayey, in the "highland" areas (Ejido Benigno Mendoza, $322 \mathrm{~m})$ have a low content $\left(<3 \mathrm{cmol} \mathrm{kg}^{-1}\right)$ of exchangeable bases $\left(\mathrm{K}^{+}, \mathrm{Ca}^{2+}\right)$, while those in the "lowland" (Tecuanapa, $25 \mathrm{~m})$ have a higher content $\left(7-15 \mathrm{cmol} \mathrm{kg}^{-1}\right)($ Guevara et al. 2006). In order to determine differences among both locations, soil samples were obtained from the first $30 \mathrm{~cm}$. Several parameters were determined: $\mathrm{pH}$, electric conductivity, 
A)<smiles>CCCc1cc(=O)oc2c3c(c4c(c12)OC(C)(C)C=C4)O[C@H](C)[C@H](C)[C@H]3O</smiles>

D)<smiles>CCCC(CC(=O)O)c1c2c(c(O)c3c1O[C@H](C)[C@@H](C)C3=O)C=CC(C)(C)O2</smiles>

B)<smiles>CCCc1cc(=O)oc2c3c(c4c(c12)OC(C)(C)C=C4)O[C@H](C)[C@H](C)[C@H]3O</smiles>

E)<smiles>C[C@H]1Oc2c3c(c4c(-c5ccccc5)cc(=O)oc4c2CC(C)(C)C=C3)[C@H](O)[C@@H](C)O1</smiles>

C)<smiles>CCCc1cc(=O)oc2c3c(c4c(c12)OC(C)(C)C=C4)O[C@H](C)[C@H](C)[C@H]3O</smiles>

F)<smiles>[R]c1c(O)c(CC=C(C)C)c(O)c2c(-c3ccccc3)cc(=O)oc12</smiles>

$\mathbf{R}^{1} \quad \mathbf{R}^{2} \quad \mathbf{R}^{3}$<smiles>CCC(C)C(C)=O</smiles>

Figure 1. Chemical compounds from C. brasiliense leaves. Chemotype 1: A) (+)- calanolide A. B) (-)- calanolide B. C) (+)- calanolide C. D) apetalic acid. E) soulatrolide. Chemotype 1 ; F) mammea $\mathrm{A} / \mathrm{BA}, \mathrm{A} / \mathrm{BB}$ and $\mathrm{A} / \mathrm{BD}$, respectively from left to right.

moisture, field capacity, and content of $\mathrm{N}, \mathrm{P}, \mathrm{K}^{+}, \mathrm{Ca}^{2+}, \mathrm{C}$, and organic matter.

The fruits were collected in November 2005 and April 2006. Vouchers specimens of the parents trees (15858) were deposited in the herbarium of Mexican Social Security Institute (IMSS) in Mexico City. The collected fruits were peeled to obtain the seeds (46-52\% water content, w/w) with the intact endocarpium, washed and treated with $0.2 \%$ Captan $\AA$ (Bayer) solution and placed in vermiculite and maintained in hydroponic conditions in a greenhouse to achieve germination. Seeds were recalcitrant due to their high water content, with $100 \%$ viability as determined by tetrazolium test. Any seed germinated 3 months after collected, thus indicating seeds are lack of dormancy

Most of the seeds germinated and developed the epicotyl and leaves, the seedlings were transplanted to $1 \mathrm{~kg}$ black plastic bags with vermiculite and irrigated for 3 months with deionized water, after this time seedlings reached an average of $16 \mathrm{~cm}$ in height. After this time, leaves morphology was identical to seedlings in the field or those growing on soil under greenhouse conditions, none showed chlorosis, necrosis, thickening, or spots. This was attributed to nutrients provided by seed cotyledons are enough to feed the seedlings for a short period of time (Figure 4, panel A).

Seedlings were randomized in 3 different groups and subjected to nutritional stress during 7 months but irrigated once daily. Treatments were: 1) Control group, Hoagland solution modified to contain all necessary macro and micronutrients for plant growth (Fernández-Hinojosa \& Johnston-Barria 1986), and prepared with the following salts: $\mathrm{Ca}\left(\mathrm{NO}_{3}\right)_{2} 4 \mathrm{H}_{2} \mathrm{O}$ (1M), $\mathrm{KNO}_{3}(1 \mathrm{M}), \mathrm{MgSO}_{4} 7 \mathrm{H}_{2} \mathrm{O}(1 \mathrm{M}), \mathrm{KH}_{2} \mathrm{PO}_{4}(1 \mathrm{M})$, chelated iron $\left(5,000 \mu \mathrm{g} \mathrm{L}^{-1}\right)$ and trace micronutrients $\left(\mathrm{MnCl}_{2}\right.$, $\mathrm{H}_{3} \mathrm{BO}_{3}, \mathrm{ZnSO}_{4} 7 \mathrm{H}_{2} \mathrm{O}, \mathrm{CuSO}_{4} 5 \mathrm{H}_{2} \mathrm{O}$ y $\mathrm{H}_{2} \mathrm{MoO}_{4} \mathrm{H}_{2} \mathrm{O}$ ). 2) Hoagland modified solution but without $\mathrm{Ca}^{2+}$. 3) Hoagland modified solution but devoid of $\mathrm{K}^{+}$. The salts $\mathrm{KNO}_{3}$, and $\mathrm{KH}_{2} \mathrm{PO}_{4}$ were replaced with $\mathrm{NaH}_{2} \mathrm{PO}_{4} \cdot \mathrm{H}_{2} \mathrm{O}$, and $\mathrm{NaNO}_{3}$. Treatments with deficiency in $\mathrm{Ca}^{2+}$ and $\mathrm{K}^{+}$were prepared as previously reported (Fernández-Hinojosa \& Johnston-Barria 1986).

Plant Extracts. After 7 months of nutrient stress treatments, 4 leaves from each seedling were collected, and dried in a laboratory oven $\left(50^{\circ} \mathrm{C}, 3\right.$ days $)$, cut in small pieces with scissors, weighted, and extracted at room temperature with hexane for one week, extraction was repeated with fresh solvent 3 
times. Extracts from each plant were pooled and filtered with Whatman filter paper (\#2, $55 \mathrm{~mm}$ diameter) and concentrated in rotavapor Büchi R-205. The extract was recovered with $\mathrm{CH}_{2} \mathrm{Cl}_{2}$ in vials. Yield in each vial was calculated after solvent evaporation in a vacuum bell for one week. The extract of each seedling was analyzed by thin layer chromatography (TLC) (Merck GF-254) applying $5 \mu \mathrm{L}$ of a solution $(60 \mathrm{mg}$ $\left.\mathrm{mL}^{-1}\right)$ to confirm the presence of the triterpenoids friedelin and canophyllol, the chromanone apetalic acid, and the dipyranocumarins calanolides B and C (see Supplemental figure). The three later compounds were next quantified by HPLC. The mobile phase was hexane-ethyl acetate 8:2. TLC plates were observed under UV light (254, and $366 \mathrm{~nm}$ ) and finally sprayed with cerium sulphate solution $1 \mathrm{~N}$ in $\mathrm{H}_{2} \mathrm{SO}_{4} 2 \mathrm{~N}$, afterwards the plates were revealed on a hot plate.

HPLC. The hexane extracts were analyzed by High Performance Liquid Chromatography HPLC (Waters 700) to quantify (-)-calanolide B (1), (+)-calanolide C (2), and apetalic acid (3) (Figure 1), using a C-18 Silica Gel column $(250 \times 4$ $\mathrm{mm}, 5 \mu \mathrm{m}$, Kromasil 100) with an UV-DAD detector (2487 DWAD, Waters Co.) at $284 \mathrm{~nm}$. The eluent was acetonitrilewater $(6 / 4, \mathrm{v} / \mathrm{v})$ using an isocratic flow $\left(1 \mathrm{~mL} \mathrm{~min}^{-1}\right)$ during $40 \mathrm{~min}$.

Authentic samples of compounds previously isolated and identified by spectroscopic and spectrometric methods (Huerta-Reyes et al. 2004) were injected in triplicate at different concentrations $(10,25,50$ and $100 \mathrm{ppm})$ to establish the relationship between concentration and absorbance (Figure 2). The linear regression equations were calculated as follows. Apetalic acid: RT $26.18 \mathrm{~min}, \mathrm{y}=46,697.95 \mathrm{x}$ - 12,223.52, $r^{2}=0.99$, pb0.05. Calanolide B: RT $32.89 \mathrm{~min}$, $\mathrm{y}=61,728 \mathrm{x}-680,388, r^{2}=0.97, \mathrm{pb} 0.05$. Calanolide C: RT $34.82 \mathrm{~min}, \mathrm{y}=40,059.51 \mathrm{x}-10,287.89, r^{2}=0.99$, pb0.05. Quantification limits apetalic acid $=0.25 \mu \mathrm{g}$, calanolide B $=3.27 \mu \mathrm{g}$ and calanolide $\mathrm{C}=0.93 \mu \mathrm{g}$, and detection limit apetalic acid $=0.02 \mu \mathrm{g}$, calanolide $\mathrm{B}=0.32 \mu \mathrm{g}$ and calanolide $\mathrm{C}=0.09 \mu \mathrm{g}$ is presented. Each extract was dissolved in acetonitrile $\left(0.75 \mathrm{mg} \mathrm{mL} \mathrm{m}^{-1}\right)$ and injected for quantification. Content of each compound is expressed as $\mathrm{mg} \mathrm{g}^{-1}$ dry leaf.
To confirm that mineral nutrition does not induce a change in the type of chemotype (chemical phenotype) in C. brasiliense seedlings, the hexane extract of chemotype 2 was analyzed by HPLC as previously described before and afterwards of addition of mammea $\mathrm{A} / \mathrm{BA}$ as a marker compound of chemotype 1 .

Statistical analysis. Contents of nutrients in soils, as well as (-)-calanolide B (1), (+)-calanolide C (2), and apetalic acid (3) in each leaf sample were subjected to Kruskal-Wallis statistical test in order to determine if differences were significant. In the case of plant growth, foliar biomass statistical tests were ANOVA one way and Tukey.

\section{Results}

Soil Analysis. The soils from the two areas from the Tropical Rain Forest Area "Los Tuxtlas", "Highland" (322 m), and "lowland" $(25 \mathrm{~m})$ both were clay type, and did not show significant differences in $\mathrm{pH}$, soil moisture, nitrates, $\mathrm{P}$, and $\mathrm{C}$. Differences were found in $\mathrm{K}^{+}, \mathrm{Ca}^{2+}$, and $\mathrm{Mg}^{2+}$, being higher for these macronutrients for the "lowland" than for "highland" location (Table 1) as previously reported (Guevara et al. 2006). $\mathrm{Mg}^{2+}$ content for both locations were close to a mean agricultural soil, however $\mathrm{K}^{+}$, and $\mathrm{Ca}^{2+}$ were fairly low as compared with agricultural soils (Table 1). Hydroponic nutrient treatments were decided on these grounds.

In order to determine the influence of $\mathrm{K}^{+}$and $\mathrm{Ca}^{2+}$ deficiency on the growth and synthesis of secondary metabolites of $C$. brasiliense, seedlings were grown under hydroponic conditions for 7 months. Absence of $\mathrm{Mg}^{2+}$ was not tested since it is essential for plant survival due to its role in chlorophylls synthesis. Excess of $\mathrm{K}^{+}$, and $\mathrm{Ca}^{2+}$ was not investigated, since it has been reported that seedlings of this species die in saline soil (Fischer \& Dos Santos 2001).

$\mathrm{Ca}^{2+}$ and $\mathrm{K}^{+}$deficiency decrease seedlings survival and growth. The survival of $C$. brasiliense (CTP2) seedlings growing under hydroponic conditions was $100 \%$ after 7 months irrigation with Modified Hoagland Solution (MHS)

\section{Cal B}

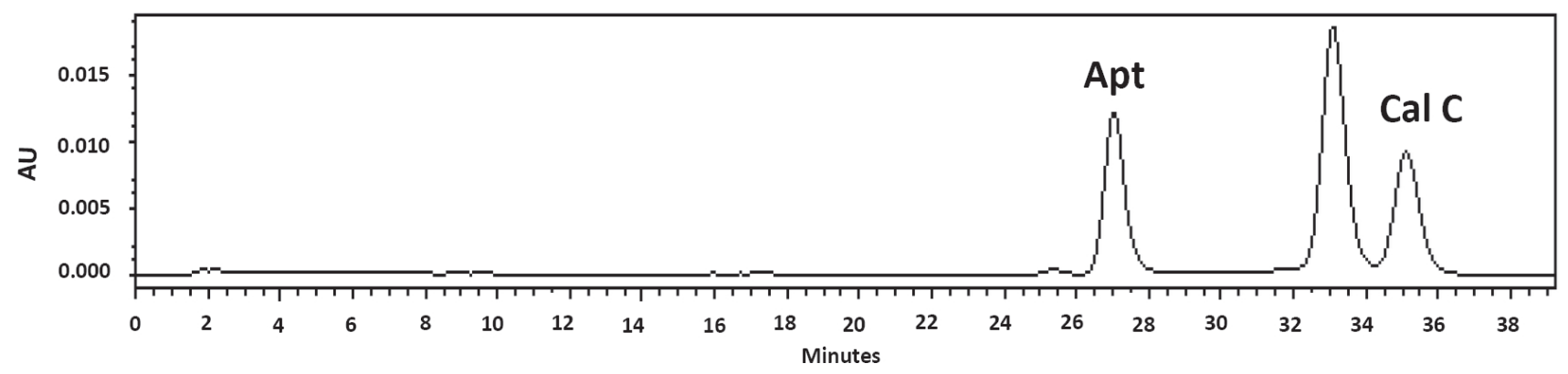

Figure 2. Time retention $(\mathrm{RT})$ of pure apetalic acid $(\mathrm{Apt}), \mathrm{RT}=26.18 \mathrm{~min}$; calanolide $\mathrm{B}(\mathrm{Cal} \mathrm{B}), \mathrm{RT}=32.89$ min and calanolide $\mathrm{C}(\mathrm{Cal} \mathrm{C}), \mathrm{RT}=$ $34.82 \mathrm{~min}(10 \mathrm{ppm})$ injected in HPLC. HPLC quantification limit (Apt $=0.25 \mu \mathrm{g}$; $\mathrm{Cal} \mathrm{B}=3.27 \mu \mathrm{g}$ and $\mathrm{Cal} \mathrm{C}=0.93 \mu \mathrm{g})$ and detection limit $(\mathrm{Apt}=0.02 \mu \mathrm{g}$; $\mathrm{Cal} \mathrm{B}=0.32 \mu \mathrm{g}$ and $\mathrm{Cal} \mathrm{C}=0.09 \mu \mathrm{g})$ is presented. 
Table 1. Chemical and physics properties of the soil simples (average values).

\begin{tabular}{|c|c|c|c|}
\hline & Highland & Lowland & $\begin{array}{l}\text { Agriculture } \\
\text { Soil } * * *\end{array}$ \\
\hline & Distric Nitrosol* (= Acrisol**) & $\begin{array}{l}\text { Chromic Luvisol* } \\
\text { (= Luvisol**) }\end{array}$ & \\
\hline $\mathrm{pH}$ & 4.57 & 5.56 & $5.8-6.5$ \\
\hline Electrical conductivity ( $\mu$ mhos) & 193 & 382.67 & $<500$ \\
\hline Color (Munsell Table) & $\begin{array}{c}5 Y R 3 / 3 \text { y } 5 \text { YR } 3 / 4 \text { Dark reddish } \\
\text { brown }\end{array}$ & $\begin{array}{c}\text { 10YR2/2 Very Dark Brown y } \\
7.5 \text { YR3/2 Dark Brown }\end{array}$ & N/A \\
\hline Soil moisture dried at room temperature (\%) & 7.66 & 6.29 & \\
\hline Saturation $(\%)$ & 54.87 & 59.23 & \\
\hline Nitrates (ppm) & 1.76 & 1.80 & $20-30$ \\
\hline Potassium $(\mathrm{cmol} / \mathrm{kg})$ & 0.0117 & 0.0203 & $>0.6$ \\
\hline Phosphorus (ppm) & 0.97 & 1.24 & $>11$ \\
\hline Calcium (cmol/kg) & 0.032 & 0.1617 & $>10$ \\
\hline Magnesium $(\mathrm{cmol} / \mathrm{kg})$ & 2.23 & 5.68 & $>3$ \\
\hline Organic matter content $(\%)$ & 4.91 & 4.16 & $3.5-6$ \\
\hline Carbon content $(\%)$ & 2.45 & 2.08 & \\
\hline Clays $(\%)$ & 72.67 & 62 & \\
\hline Silt (\%) & 24 & 36 & \\
\hline Sand $(\%)$ & 3.33 & 2 & \\
\hline Textural class & Clayey & Clay and clay loam & \\
\hline
\end{tabular}

* Guevara 2006.

** INEGI 2009.

*** Marx \& Hart 1996.

which includes all nutrients. The seedlings grew adequately and reached a mean of $84 \mathrm{~cm}$ in height and 3,347 $\mathrm{mg}$ (dry weight) of foliar biomass (Figure 3), their growth was comparable to that described in literature for this species growing in soil in plantations (Fischer \& Dos Santos 2001). Therefore, growth was associated with an adequate nutrition with MHS.

However, $\mathrm{Ca}^{2+}$ and $\mathrm{K}^{+}$deficiency fairly decreased the survival and growth of the seedlings after 7 months treatment. MHS $-\mathrm{Ca}^{2+}$ treatment caused the death of $53 \%$ of the seedlings. The leaves of surviving seedlings were yellowish in color, and most of them without new leaves buds (Figure. 4, panel C). MHS- $\mathrm{K}^{+}$treatment caused the death of $28 \%$ of the seedlings. The surviving seedlings showed first necrosis in the leaves margins leading to withered leaves; however, seedlings developed new leaves buds (Figure 4, panel D). The foliar biomass and plant height of seedlings irrigated with (MHS-Ca ${ }^{2+}$ ) or (MHS- $\mathrm{K}^{+}$) were 6 and 4 times lower as compared with seedlings watered with HMS (Figure 3).

$\mathrm{Ca}^{2+}$ or $\mathrm{K}^{+}$deficiency did not induce a change in the chemotype of $C$. brasiliense seedlings. Deficiency in $\mathrm{Ca}^{2+}$ or $\mathrm{K}^{+}$ did not induced a change in the type of chemotype (chemical phenotype) in C. brasiliense seedlings, as indicated by HPLC analysis. Therefore, the hexane extracts of the leaves of Chemotype 2 seedlings subjected to deficiency in $\mathrm{Ca}^{2+}$ or $\mathrm{K}^{+}$did not showed mammea A/BA, the marker compound of chemotype 1 .

$\mathrm{Ca}^{2+}$ and $\mathrm{K}^{+}$are required for apetalic acid and calanolide $B$ biosynthesis in $C$. brasiliense. The seedlings subjected to nutrition stress for 7 months did not showed qualitative changes in the type of secondary metabolites biosynthesized (Figure 5), but their concentration was reduced. The yields 
A)

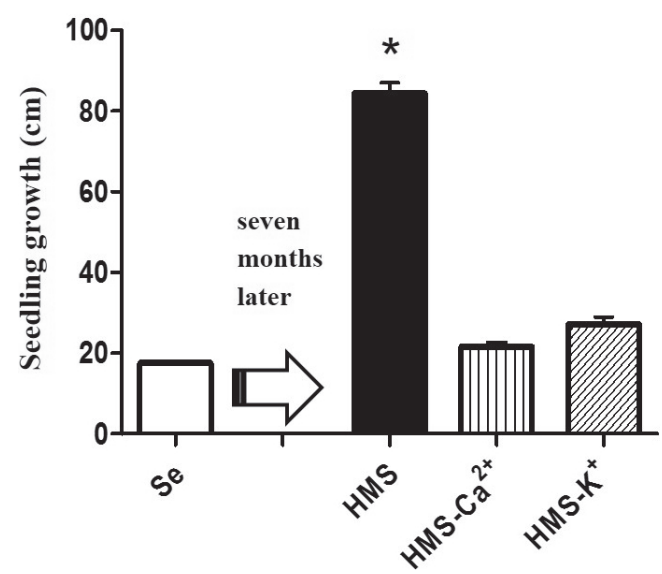

B)

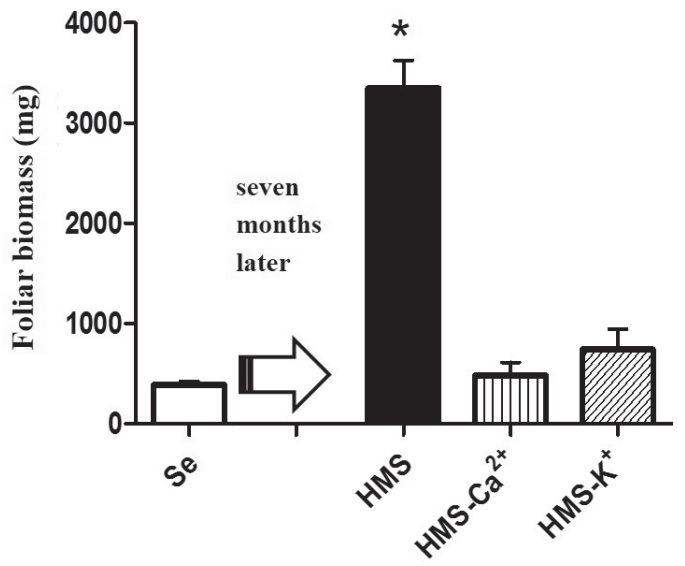

Figure 3. Growth of $C$. brasiliense seedlings. A) Stem length. B) Leaf biomass. $\mathrm{N}=16$ (Se), 25 (MHS), 7 (MHS-Ca ${ }^{2+}$ ) and 12 (MHS-K ${ }^{+}$), ANOVA $p=0.000 \alpha=0.005$, Tukey $p=0.000$. Se: Seedling irrigated with deionized water (3 months). MHS: Seedlings irrigated with Modified Hogland Solution, MHS- $\mathrm{Ca}^{2+}$, or MHS $-\mathrm{K}^{+}$.

of apetalic acid of seedlings irrigated with MHS (2.4-3.1 $\mathrm{mg} \mathrm{g}^{-1}$ ) were similar to those watered with deionized water before starting the treatment or compared with trees growing in field conditions (WT). Nevertheless, deficiency in potassium $\left(\right.$ MHS- $\mathrm{K}^{+}$) induced a decrease of 4.3 -fold as compared with MHS, while calcium deficiency (MHS-Ca ${ }^{2+}$ ) treatment did not showed statistical differences with MHS. The yields of calanolide B of plants irrigated with MHS were like those
A)

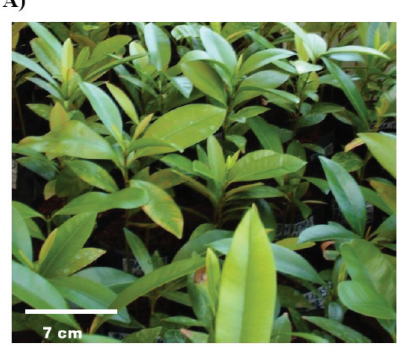

C)

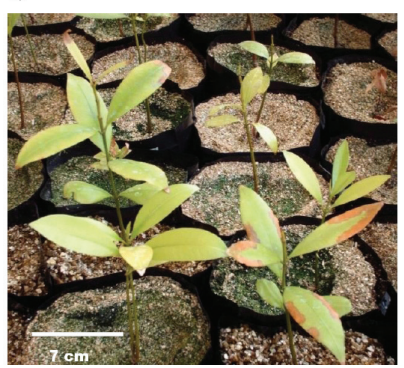

B)

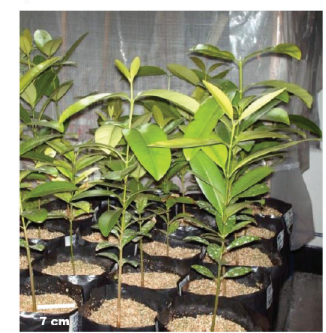

D)

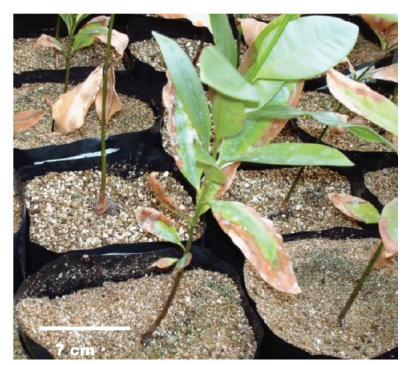

Figure 4. C. brasiliense seedlings (A) Germinated and irrigated with deionized water for 3 months; Mean stem length $=17 \mathrm{~cm}$. (B) Watered with MHS after 7 months, mean stem length $=84 \mathrm{~cm}$; (C) Watered with MHS-Ca ${ }^{2+}$ after 7 months, mean stem length $=21 \mathrm{~cm}$; (D) Watered with MHS- $\mathrm{K}^{+}$after 7 months, mean stem length $=27 \mathrm{~cm}$. watered with deionized water before starting the treatment or WT (2.8-3.7 $\left.\mathrm{mg} \mathrm{g}^{-1}\right)$. Nevertheless potassium $\left(\mathrm{MHS}-\mathrm{K}^{+}\right)$and calcium deficiency treatment (MHS- $\mathrm{Ca}^{2+}$ ) induced a decrease of 15 and 4.3 -fold, respectively as compared with MHS. The yields of calanolide $\mathrm{C}$ of plants irrigated with MHS were 2.6 and 3.0-fold higher to those watered with deionized water and WT $\left(0.29\right.$ and $\left.0.25 \mathrm{mg} \mathrm{g}^{-1}\right)$. Potassium (MHS-K ${ }^{+}$and calcium (MHS- $\mathrm{Ca}^{2+}$ ) deficiency treatment induced a decrease of 2.4 and 4.2-fold, respectively as compared with MHS. Therefore, calcium and potassium are necessary for yield of (-)-calanolide B (1), (+)-calanolide C (2). In the case of apetalic acid, potassium, but not calcium, is a yield restraint (Figure 6).

\section{Discussion}

Role of nutrients. Biosynthesis of secondary plant metabolites is influenced due to the content of soil macronutrients, and several deprival treatments have been designed under different experimental conditions, including hydroponia eliminating one or several nutrients (Verma \& Shukla 2015, Borges et al. 2017). We have focused in the role of $\mathrm{Ca}^{2+}$ and $\mathrm{K}^{+}$, since are the limiting nutrients in the soils where the tropical tree Calophyllum brasiliense grows. Our results show that $\mathrm{Ca}^{2+}$ or $\mathrm{K}^{+}$deficiency cause the death of $53 \%$ and $28 \%$ respectively, of the seedlings growing under hydroponic conditions (MHS) after 7 months. The foliar biomass and plant height of the survivor seedlings were also drastically reduced, due the importance of these elements as essential macronutrients (Taiz \& Zeiger 2010).

The deficiency of $\mathrm{Ca}^{2+}$ or $\mathrm{K}^{+}$also induce a decrease on the concentration of the phenolic compounds apetalic acid, calanolide B and C in the leaves. Since MHS contain all micro and macronutrients, our results remark the importance of $\mathrm{Ca}^{2+}$ and $\mathrm{K}^{+}$on the survival, biomass, and yield of these 

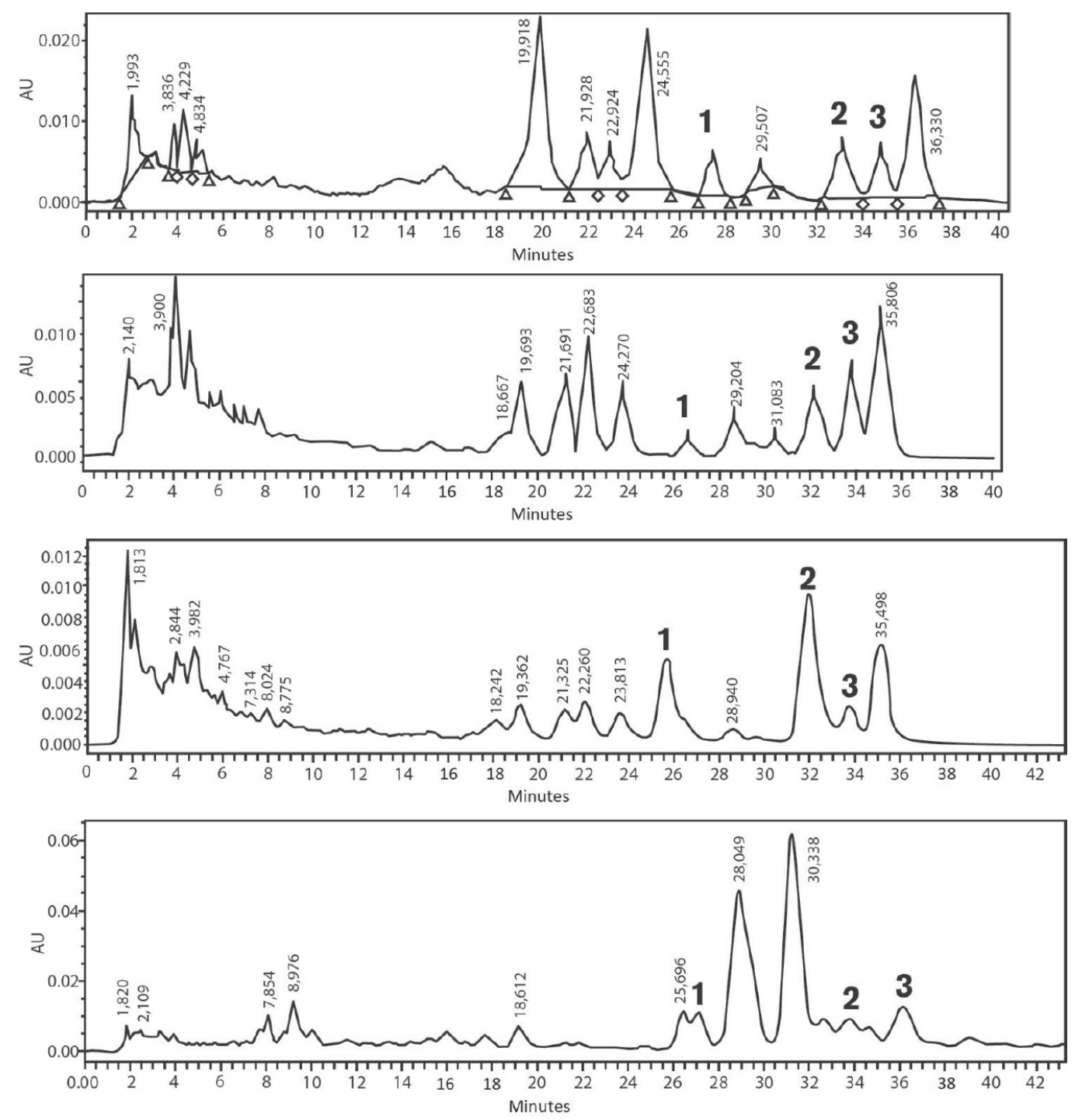

Figure 5. Chromatographic patterns by HPLC of foliar extracts to seedlings of C. brasiliense grown in hydroponics. A) Seedling irrigated with deionized water. B) Seedlings irrigated with Modified Hogland Solution, C) MHS-Ca ${ }^{2+}$, and D) MHS $-\mathrm{K}^{+}$. 1) apetalic acid, 2) calanolide B and 3) calanolide $\mathrm{C}$.

secondary metabolites of $C$. brasiliense. Since soil in the tropical areas where this species grow is deficient in cations, these may be a limiting factor for seedling survival in natural conditions (Martinez-Sanchez 2006).

The physiological and ecological role of apetalic acid and calanolides remains to be thoroughly investigated, but possibly are chemical defenses. For instance, apetalic acid and calanolide $\mathrm{B}$ increase in $C$. brasiliense seedlings attacked by fungi in 10 and 7 times, respectively (Bernabé-Antonio et al. 2010). These metabolites could also be important in protection against tissue injury caused by herbivores, and as antioxidants, especially in growing tissues and during differentiation. Therefore, it seems that under limited nutrition, seedling allocate their resources for survival, but not to antifungal defense.
Other authors have also reported that the deficiency of $\mathrm{Ca}^{2+}$ and $\mathrm{K}^{+}$decreased the concentration phenolic compounds, as instance for the boreal gymnosperm tree Pseudotsuga menziesii var. glauca under hydroponic conditions. For this species, deficiency in soil $\mathrm{K}^{+}$, but also $\mathrm{N}$, significantly diminished the biosynthesis of phenolic compounds and tannins in the roots of seedlings (Shaw et al. 1998). In chickpea plants (Cicer arietinum L.) deficiency in $\mathrm{Ca}^{2+}$ and $\mathrm{K}^{+}$also reduced the content of total phenols, flavonoids, and increases its susceptibility to cadmium toxicity (Ahmad et al. 2016). In the case of the gymnosperm tree Picea abies (L.) $\mathrm{H}$. Karst, $\mathrm{K}^{+}$deficiency in the leaves was correlated with an increased expression of the polyamine putrescine (Lauchert \& Wild 1995). In the case of Anthriscus cerefolium Hoffm. it was observed that the fertilization with $\mathrm{K}^{+}$, favored the pro- 
A)

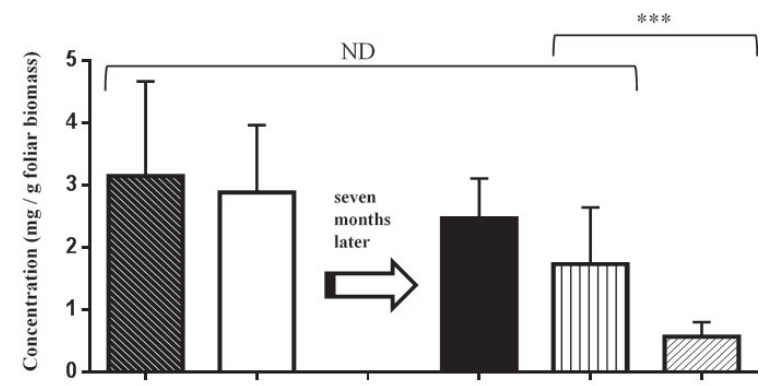

B)

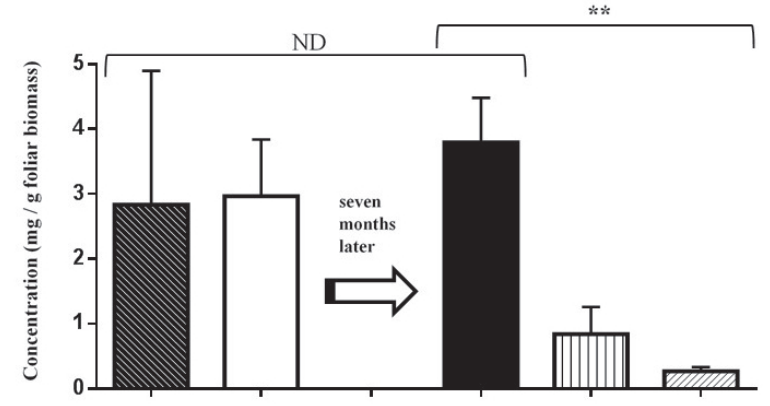

C)

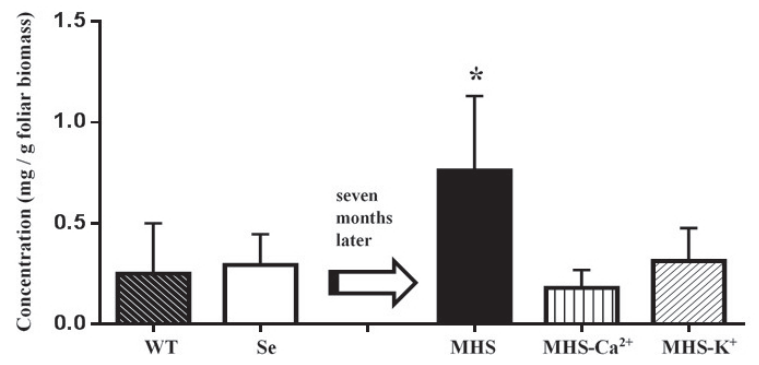

Figure 6. Yields of apetalic acid (A), calanolide B (B) and calanolide $\mathrm{C}(\mathrm{C})$ in wild trees (WT) and seedlings of $C$. brasiliense grown in hydroponics. $\mathrm{N}=4$ (WT), 16 (Se), 25 (MHS), 7 (MHS-Ca ${ }^{2+}$ ) and 12 $\left(\mathrm{MHS}-\mathrm{K}^{+}\right)$seedling for treatment $(* * * p=0.003 ; * * p=0.034, p=0.002$, $* p=0.047 ; \alpha=0.05) . \mathrm{ND}=$ It's not different. Se: Seedling irrigated with deionized water (3 months). MHS: Seedlings irrigated with Modified Hogland Solution, MHS-Ca ${ }^{2+}$, or MHS $-\mathrm{K}^{+} .0$

duction of biomass, the percentage of essential oils and the production of oxygenated compounds and sesquiterpenes, but not of monoterpenes (El Gendy et al. 2015).

Interestingly, the in vitro culture tissues without $\mathrm{Ca}^{2+}$ of the medicinal herb Silybum marianum (L.) Gaertn., showed a $40 \%$ increase in the production of flavolignans known as silimarin with hepatoprotective properties (Sánchez-Sampedro et al. 2005). Vitex agnus-castus L. watered with a solution deficient in $\mathrm{K}^{+}$, increases vitexin in $18 \%$, while deficiency in $\mathrm{Ca}^{2+}$ induce a $22 \%$ decrease of this compound in the leaves (Mendonça-Freitas et al. 2008).

The role of nitrogen has also been studied in relation to the biosynthesis of secondary metabolites, especially in medicinal plants. The deficiency in soil nitrogen for 7 and 15 days, respectively in Matricaria chamomilla L. and Hordeum vulgare L. plants induces the synthesis of secondary metabolites containing $\mathrm{C}$, but not those with $\mathrm{N}$ (Kováčik \& Klejdus 2014, Kováčik et al. 2014). Something similar was reported that reducing soil nitrogen induces an increase in the synthesis of flavonoids in Chrysanthemum morifolium Ramat. (Liu et al. 2010). Differing concentrations of nitrogen applied to Artemisia annua L. plants enhanced biomass production, and artemisinin concentration was maximal at a nitrogen application of $106 \mathrm{mg} \mathrm{L}^{-1}$ but declined at higher concentrations; potassium applications enhanced leaf potassium concentration, but there was no effect on leaf artemisinin concentration (Davies et al. 2009).

The deficiency of three essential elements as nitrogen, phosphorus and potassium (N, P. $\mathrm{K}^{+}$), increase the synthesis of phenolic compounds in Salix sericea (Glynn et al. 2007), while the opposite occurs in the production of furanocumarins of Pastinaca sativa L. (Zangerl \& Berenbaum 1987) and in the synthesis of stevioside and rebaudioside-A by Stevia rebaudiana Bertoni ( $\mathrm{Pal}$ et al. 2015). The general deficiency of nutrients may favor the synthesis of secondary metabolites, as has been proven in Origanum vulgare L in which a significant increase in both total phenolic content and rosmarinic acid was observed, the most representative phenolic compound in oregano shoot extracts (Lattanzio et al. 2009), as well as in Tithonia diversifolia Hemsl. A. Gray when the concentrations of macronutrients in the soil decreased, the phenolic compounds increased, especially esters of trans-cinnamic acid derivatives (Sampaio et al. 2016), and in Theobroma cacao the quantity of caffeic acid aspartate was significantly higher in seeds from not fertilized locations (Elwers et al. 2009). Species adapted to low-nutrient availability generally have higher defense allocations than species of resources rich-habitats. In conditions of nutrient deficiency, if plants maintain defensive compound levels as nutrient resources decline, then growth and other competing physiological processes may decreased (Caretto et al. 2015).

Role of genetics. The chemotype of a plant species has traditionally been defined as its chemical phenotype (Desjardins 2008). Since, biosynthesis of secondary plant metabolites is under genetic control, but may be regulated due to environmental properties, such as nutrient content in soils (Verma \& Shukla 2015), it was interesting to us to determine if the existence of two chemotypes in C. brasiliense could be due to soil nutrients.

The treatments MHS- $\mathrm{Ca}^{2+}$ and MHS- $\mathrm{K}^{+}$did not induce a shift of the the chemotype from 2 to 1 , since the synthesis of mammea coumarins characteristic of chemotype 1 was not induced, suggesting that chemotype is under genetic control. The fact that mammea coumarins were not detected by TLC and HPLC (data not shown) favors the hypothesis that $C$. brasiliense chemotypes are genetically determined, instead than derived from environmental conditions regulating plant physiology and biochemistry. Previous studies of collections of C. inophyllum L. of the islands of French Polynesia show that this tree species also has a high variability in the content of secondary metabolites between populations of different islands (Laure et al. 2008). However they do not indicate what may be the reason why this phenomenon occurs in this species (Burney \& Jacobs 2011) suggested the difference 
in resource allocation by species depends greatly upon the specific chemical defensive compounds produced. The pathways by which plants respond to the introduction of supplemental nutrition are increased growth, secondary metabolite production, or some combination of both depending upon species, phenological stage, age and genetics.

Therefore our results indicate that nutrition is not determining the existence of the two chemotypes of $C$. brasiliense populations previously described (Huerta-Reyes et al. 2004, Reyes-Chilpa et al. 2004), and suggest that are genetically determined, as found for common Dandelion, Taraxacum officinale L. (Huber et al. 2016). This species synthesizes the sesquiterpene lactone taraxinic acid $\beta$-D-glucopyranosyl ester (TA-G) in the roots due to activity of germacrene A synthase, responsible of the first step in the biosynthesis of TA-G with has a defensive role against the feeding activity of beetle larvae Melolontha melolontha. The genes encoding this enzyme can be differentially expressed in distinct genotypes with low, medium and high production of TA-G (Huber et al. 2016).

Tropical Rain Forest are the ecosystems with the highest richness of vegetal diversity on earth; however, few studies are available for trees, since are slow growing plants, and with life spans of centuries; in addition, it is difficult to collect seeds and establish conditions for germination and obtain seedlings. Most studies are performed in annual plants of rapid growth and short life cycles, specially domesticated with economic importance. In this context, this paper provides relevant information on the physiology, and secondary metabolism of the tropical rain forest tree C. brasiliense. Specifically, our results demonstrate the role calcium as an essential element in the survival of $C$. brasiliense seedlings, and exhibit the importance of calcium and potassium as cofactors in the growth and foliar mass production, and the biosynthesis of the pharmacologically important compounds chromanone apetalic acid, and the dipiranocoumarin calanolide B. In addition, our results indicate that nutrition is not determining the existence of the two chemotypes of $C$. brasiliense populations previously described and suggest that are genetically determined. This information is relevant, since the original vegetation where $C$. brasiliense grows, has been deforestated during the last 70 decades in sake of cattle breeding and agriculture, the abandoned lands give rise to a secondary vegetation named locally as "acahual". Therefore is important to understand this species physiology for future reforestation.

In conclusion, when an adequate nutrition (MHS) is provided, the foliar biomass and height of $C$. brasiliense seedlings under hydroponia increased in a similar way to seedlings growing in plantations. The yields of apetalic acid and calanolide B were also similar for MHS, WT (wild trees), or $\mathrm{Se}$ (deionized water), only calanolide C increased in MHS treatment. However, when $\mathrm{Ca}^{2+}$ or $\mathrm{K}^{+}$are absent from the nutritive solution, the biomass and height seedling did not increased, and a downtrend yield of all of these compounds was recorded. (Figures 3 and 6). Therefore, under limited nutrition, seedling allocate their resources for survival, but not to antifungal defense.

\section{Acknowledgement}

This work was partial supported by National Autonomous University of Mexico under project IN210016 DGAPA-PAPIIT-UNAM. To Professors Nelly del Carmen Jiménez, Abigail Aguilar, and Mr. Marcelino Ortega for collecting and botanical determination of $C$. brasiliense. To Professor. Arturo Navarro Ocaña for HPLC-facilities. Biologists Ana Vianey Rivera Santamaría for collaboration on statistics analysis, Patricia Olguín Santos carried out greenhouse work.

\section{Literature cited}

Ahmad P, Abdel A, Abd_Allah E, Hashem A, Sarwat M, Anjun N, Gucel S. 2016. Calcium and Potassium Supplementation Enhanced Growth, Osmolyte Secondary Metabolite Production, and Enzymatic Antioxidant Machinery in CadmiumExposed Chickpea (Cicer arietinum L.). Frontiers in Plant Science 7. DOI: http://doi.org/10.3389/fpls.2016.00513

Ajithabai M, Rameshkumar B, Jayakumar G, Luxmi V, Mangalam S, Ajaikumar, Gayathri P. 2012. Decipic acid and 12-acetyl apetalic acid from Calophyllum decipiens. Indian Journal Chemistry 51: 393-397

Alaoui C, Kasrati A, Bekkouche K, Hassani L, Wohlmuth H, Leach D, Abbad A. 2014. Cultivation and the application of inorganic fertilizer modifies essential oil composition in two Moroccan species of Thymus. Industrial Crops and Products 62: 113-118.

DOI: http://doi.org/10.1016/j.indcrop.2014.08.017

Bernabé-Antonio A, Estrada-Zúñiga M, Buendía-González L, Reyes-Chilpa R, Chávez-Avila V, Cruz-Sosa F. 2010. Production of anti-HIV-1 calanolides in a callus culture of $\mathrm{Ca}$ lophyllum brasiliense (Cambes). Plant Cell Tissue Organ Culture 103: 33-40.

DOI: http://doi.org/10.1007/s11240-010-9750-4

Boeger M, Wisniewski C. 2003. Comparação da morfologia foliar de espécies arbóreas de três estádios sucessionais distintos de floresta ombrófila densa (Floresta Atlântica) no Sul do Brasil. Brazilian Journal of Botany 26: 61-72. DOI: http://doi.org/10.1590/S0100-84042003000100007

Borges C, Minatel I, Gomez-Gomez H, Pereira L. 2017. Medicinal plants: Influence of environmental factors on the content of secondary metabolites. Medicinal Plants and Environmental Challenges.

DOI: http://doi.org/10.1007/978-3-319-68717-9_15

Burney O, Jacobs D. 2011. Ungulate herbivory of regenerating conifers in relation to foliar nutrition and terpenoid production. Forest Ecology Management 262: 1834-1845. DOI: http://doi.org/10.1016/j.foreco.2011.07.035

Butler M. 2008. Natural products to drugs: natural product-derived compounds in clinical trials. Natural Products Reports 25: 475. DOI: http://doi.org/10.1039/b514294f

Caretto S, Linsalata V, Colella G, Mita G, Lattanzio V. 2015. Carbon fluxes between primary metabolism and phenolic pathway in plant tissues under stress. International Journal of Molecular Sciences 16: 26378-26394

DOI: http://doi.org/10.3390/ijms161125967

Churngchow N, Rattarasarn M. 2001. Biosynthesis of scopoletin 
in Hevea brasiliensis leaves inoculated with Phytophthora palmivora. Journal of Plant Physiology 158: 875-882. DOI: http://doi.org/10.1078/0176-1617-00230

Cornelissen T, Stiling P. 2006. Responses of different herbivore guilds to nutrient addition and natural enemy exclusion. Ecoscience 13: 66-74. DOI: http://doi.org/10.2980/11956860(2006)13[66:RODHGT]2.0.CO;2

Davies MJ, Atkinson CJ, Burns C, Woolley JG, Hips NA, Arroo RRJ, Dungey N, Robinson T, Brown P, Flockart I, Hill C, Smith L, Bentley S. 2009. Enhancement of artemisinin concentration and yield in response to optimization of nitrogen and potassium supply to Artemisia annua. Annals of Botany 104: 315-323. DOI: http://doi.org/10.1093/aob/mcp126

De Carvalho L, Amaral A, Davide A . 2006. Classificação de sementes florestais quanto ao comportamento no armazenamento. Revista Brasileira de Sementes 28: 15-25 DOI: http://doi.org/10.1590/S0101-31222006000200003

Desjardins A. 2008. Natural product chemistry meets genetics: When is a genotype a chemotype? Journal of Agricultural and Food Chemistry 56: 7587-7592

DOI: http://doi.org/10.1021/jf801239j

El Gendy A, El Gohary A, Omer E, Hendawy S, Hussein M, Petrova V, Stanchev I. 2015. Effect of nitrogen and potassium fertilizer on herbage and oil yield of chervil plant ( $A n-$ thriscus cerefolium L.). Industrial Crops and Products 69: 167-174. DOI: http://doi.org/10.1016/j.indcrop.2015.02.023

Elwers S, Zambrano A, Rohsius C, Lieberei R. 2009. Differences between the content of phenolic compounds in Criollo, Forastero and Trinitario cocoa seed (Theobroma cacao L.). European Food Research and Technology 229: 937-948. DOI: http://doi.org/10.1007/s00217-009-1132-y

Fernández-Hinojosa G, Johnson-Barria M .1986. Fisiología vegetal experimental. San José, Costa Rica: Instituto Interamericano de Cooperación para la agricultura. ISBN: 9789290390664

Fischer E, Dos Santos F. 2001. Demography, phenology and sex of Calophyllum brasiliense (Clusiaceae) trees in the Atlantic forst. Journal of Tropical Ecology 17: 903-909.

DOI: http://doi.org/10.1017/S0266467401001675

Forkner R, Hunter M. 2000. What goes up must come down? Nutrient addition and predation pressure on oak herbivores. Ecology 81: 1588-1600. DOI: http://doi.org/10.1890/00129658(2000)081[1588:WGUMCD]2.0.CO;2

García-Zebadúa J, Reyes-Chilpa R, Huerta-Reyes M, CastilloArellano J, Santillán-Hernández S, Vázquez-Astudillo B, Mendoza-Espinoza J. 2014. "El árbol tropical Calophyllum brasiliense: Una revisión botánica, química y farmacológica". Vitae 21:126-145

Glynn C, Herms D, Orians C, Hansen R, Larsson S. 2007. Testing the growth-differentiation balance hypothesis: Dynamic responses of willows to nutrient availability. New Phytologist 176: 623-634.

DOI: http://doi.org/10.1111/j.1469-8137.2007.02203.x

Guevara S, Laborde D, Sánchez-Ríos G. 2006. Los Tuxtlas: El paisaje de la sierra. México: Instituto de Ecología. ISBN: 970-709-043-X, 9789707090439

Hua J, Moon T, Hong T, Park K, Son J, Chang H. 2008. 5-Methoxy-8-(2-hydroxy-3-buthoxy-3-methylbutyloxy)-psoralen isolated from Angelica dahurica inhibits cyclooxygenase2 and 5-lipoxygenase in mouse bone marrow-derived mast cells. Archives of Pharmacal Research 31: 617-621. DOI: http://doi.org/10.1007/s12272-001-1202-9

Huber M, Epping J, Schulze G, Fricke J. Aziz Z, Brillatz T, Swyers M, Köllner T, Vogel H, Hammerbacher A, Triebwasser-Freese D, Robert C, Verhoeven K, Preite V, Gershenzon J, Erb M. 2016. A Latex Metabolite Benefits Plant Fitness under Root Herbivore Attack. PLOS Biology 14. DOI: http://doi.org/10.1371/journal.pbio.1002332

Huerta-Reyes M, Basualdo M, Abe F, Jimenez-Estrada M, Soler C, Reyes-Chilpa R. 2004. HIV-1 inhibitory compounds from Calophyllum brasiliense leaves. Biological and Pharmaceutical Bulletin 27: 1471-1475.

DOI: http://doi.org/10.1248/bpb.27.1471

INEGI. 2009. [Instituto Nacional de Geografía Estadística] México. <www.inegi.org.mx/geo/contenidos/recnat/edafologia/> (accessed 20 September, 2002)

Kashman Y, Gustafson K, Fuller R, Cardellina II J, McMahon J, Currens M, Buckheit Jr R, Hughues S, Cragg G, Boyd R. 1992. HIV inhibitory natural products. Part 7. The calanolides, a novel HIV-inhibitory class of coumarin derivatives from the tropical rainforest tree, Calophyllum lanigerum. Journal of Medicinal Chemistry 35: 2735-2743.

DOI: http://doi.org/10.1021/jm00093a004

Kováčik J, Klejdus B. 2014. Induction of phenolic metabolites and physiological changes in chamomile plants in relation to nitrogen nutrition. Food Chemistry 142: 334-341. DOI: http://doi.org/10.1016/j.foodchem.2013.07.074

Kováčik J, Klejdus B, Babula P, Jarošová M. 2014. Variation of antioxidants and secondary metabolites in nitrogen-deficient barley plants. Journal of Plant Physiology 171: 260-268. DOI: http://doi.org/10.1016/j.jplph.2013.08.004

Lattanzio V, Cardinali A, Ruta C, Morone F, Lattanzio V, Linsalata V, Cicco N. 2009. Relationship of secondary metabolism to growth in oregano (Origanum vulgare L.) shoot cultures under nutritional stress. Environmental and Experimental Botany 65: 54-62.

DOI: http://doi.org/10.1016/j.envexpbot.2008.09.002

Lauchert U, Wild A. 1995. Studies on the Correlation of Putrescine and Potassium Contents in the Needles of Spruce Trees. Journal of Plant Physiology 147: 267-269.

DOI: http://doi.org/10.1016/S0176-1617(11)81516-6

Laure F, Raharivelomanana P, Butaud J, Bianchini J, Gaydou E. 2008. Screening of anti-HIV-1 inophyllums by HPLC-DAD of Calophyllum inophyllum leaf extracts from French Polynesia Islands. Analytica Chimica Acta 624:147-153. DOI: http://doi.org/10.1016/j.aca.2008.06.046

Lim T, Lim Y, Yule C. 2017. Distribution and caracterisation of phenolic compounds in Macaranga pruinosa and associated soils in a tropical peat swamp forest. Journal of Tropical Forest Science 29:509-518. DOI: http://doi.org/10.26525/jtfs2017.29.4.509518

Liu W, Zhu D, Liu DW, Liu DH, Geng M, Zhou W, Mi W, Yang T, Hamilton D. 2010. Influence of nitrogen on the primary and secondary metabolism and synthesis of flavonoids in Chrysanthemum morifolium Ramat. Journal of Plant Nutrition 33: 240-254. 
DOI: http://doi.org/10.1080/01904160903434287

Martinez-Sanchez J. 2006. Pasture trees in tropical Mexico: the effect of soil nutrients on seedling growth. Revista de Biología Tropical 54: 363-370

Marx E, Hart J. 1996. Soil test interpretation guide. No. 1478. Oregon: Oregon State University Extension Service. $<$ https:// ir.library.oregonstate.edu/downloads $/ 00000020 \mathrm{~g}>$ (Accessed 12-29-2018)

McKee T, Covington C, Fuller R, Bokesch H, Young S, Cardellina J, Kadushin M, Soejarto D, Stevens P, Cragg G, Boyd M. 1998. Pyranocoumarins from tropical species of the genus Calophyllum: A chemotaxonomic study of extracts in the National Cancer Institute Collection. Journal of Natural Products 61: 1252-1256. DOI: http://doi.org/10.1021/np980140a

Mendonça-Freitas M, Monnerat P, Curcino-Vieira J. 2008. Mineral deficiency in Passiflora alata curtis: Vitexin bioproduction. Journal of Plant Nutrition 31: 1844-1854.

DOI: http://doi.org/10.1080/01904160802325552

Milošević T, Milošević N, Glišić I, Bošković-Rakocević L, Milivojević J. 2013. Fertilization effect on trees and fruits characteristics and leaf nutrient status of apricots which are grown at Cacak region (Serbia). Scientia Horticulturae (Amsterdam) 164: 112-123.

DOI: http://doi.org/10.1016/j.scienta.2013.09.028

Muzika R, Pregitzer K, Hanover J. 1989. Changes in terpene production following nitrogen fertilization of grand fir (Abies grandis (Dougl.) Lindl.) seedlings. Oecologia 80: 485-489. DOI: http://doi.org/10.1007/BF00380070

Nerg A, Kainulainen P, Vuorinen M, Hanso M, Holopainen J, Turkela T. 1994. Seasonal and geographical variation of terpenes, resin acids and total phenolics in nursery grown seedlings of Scots pine (Pinus sylvestris L.). New Phytologist 128:703-713.

DOI: http://doi.org/10.1111/j.1469-8137.1994.tb04034.x

Pal P, Kumar R, Guleria V, Mahajan M, Prasad R, Pathania V, Gill B, Singh D, Chand G, Singh B, Singh R and Singh P. 2015. Crop-ecology and nutritional variability influence growth and secondary metabolites of Stevia rebaudiana Bertoni. BMC Plant Biology 15.

DOI: http://doi.org/10.1186/s12870-015-0457-x

Pavarini DP, Pavarini SP, Niehues M, Lopes NP. 2012. Exogenous influences on plant secondary metabolite levels. Animal Feed Science and Technology 176: 5-16.

DOI: http://doi.org/10.1016/j.anifeedsci.2012.07.002

Akula R, Ravishankar G. 2011. Influence of abiotic stress signals on secondary metabolites in plants. Plant Signaling \& Behavior 6: 1720-1731

DOI: http://doi.org/10.4161/psb.6.11.17613

Resende A, Furtini-Neto A, Curi N, Muniz J, Faria M. 2000. Accumulation and nutritional efficiency of macronutrients in

Associated editor: Martín Mata-Rosas

Author Contributions: JICA: Performed the hydroponic experiments, wrote the manuscript. HROF: performed the soil analysis and supported the greenhouse work. MMM and RGC: carried out the HPLC analysis. RRC: Coordinated the whole work, reviewed and wrote the final manuscript. forest species of different successional groups in response to phosphorus fertilizer application. Ciência e Agrotecnologia 24: $160-173$

Reyes-Chilpa R, Estrada-Muñiz E, Ramírez-Apan T, Amekraz B, Aumelas A, Jankowski C, Vázquez-Torres M. 2004. Cytotoxic effects of mammea type coumarins from Calophyllum brasiliense. Life Sciences 75:1635-1647.

DOI: http://doi.org/10.1016/j.lfs.2004.03.017

Reyes-Chilpa R, Estrada-Muñiz E, Vega-Ávila E, Abe F, Kinjo J, Hernández-Ortega S. 2008. Trypanocidal constituents in plants. 7. Mammea-type coumarins. Memórias do Instituto Oswaldo Cruz 103: 431-436.

DOI: http://doi.org/10.1590/S0074-02762008000500004

Sampaio B, Edrada-Ebel R, Da Costa F. 2016. Effect of the environment on the secondary metabolic profile of Tithonia diversifolia: A model for environmental metabolomics of plants. Scientific Reports 6: 29265

DOI: http://doi.org/10.1038/srep29265

Sánchez-Sampedro M, Fernández-Tárrago J, Corchete P. 2005. Enhanced Silymarin accumulation is related to calcium deprivation in cell suspension cultures of Silybum marianum (L.) Gaertn. Journal of Plant Physiology 162: 1177-1182. DOI: http://doi.org/10.1016/j.jplph.2005.01.012

Shaw T, Moore J, Marshall J. 1998. Root chemistry of Douglasfir seedlings grown under different nitrogen and potassium regimes. Canadian Journal of Forest Research 28: 15661573. DOI: http://doi.org/10.1139/cjfr-28-10-1566

Shen Y, Wang L, Khalil A, Kuo Y. 2004. Chromanones and dihydrocoumarins from Calophyllum blancoi. Chemical and Pharmaceutical Bulletin 52: 402-405.

DOI: http://doi.org/10.1248/cpb.52.402

Silveira S, Cordeiro-Silva R, Degenhardt-Goldbach J, Quoirin M. 2016. Micropropagation of Calophyllum brasiliense (Cambess.) from nodal segment. Brazilian Journal of Biology 76: 656-663. DOI: http://doi.org/10.1590/1519-6984.23714

Taiz L, Zeiger E . 2010. Plant Physiology. Sinauer Associates Inc. ISBN: 978-0-87893-866-7.

Verma N, Shukla S. 2015. Impact of various factors responsible for fluctuation in plant secondary metabolites. Journal of Applied Research on Medicinal and Aromatic Plants 2: 105-113 DOI: http://doi.org/10.1016/j.jarmap.2015.09.002

Vozzo J. 2002. Tropical Tree Seed Manual. Native Plants (Vol. 5). DOI: http://doi.org/10.1353/npj.2004.0004

Zangerl A, Berenbaum M .1987. Furanocoumarins in wild parsnip: effects of photosynthetically active radiation, ultraviolet light, and nutrients. Ecology 68: 516-520.

DOI: http://doi.org/10.2307/1938456

Zavaleta-Mancera H. 2011. Leaf structure of two chemotypes of Calophyllum brasiliense from Mexico. Microscopy and Microanalysis 17: 340-341

DOI: http://doi.org/10.1017/S1431927611002571 